\title{
LEMBAH KAIN MENJADI MASKER YANG MEMPUNYAI NILAI ESTETIKA DAN EKONOMIS
}

\author{
Ida Mustikawati \\ Progam Studi Ilmu Administrasi Negara \\ Sekolah Tinggi Ilmu Administrasi Pembangunan Jember \\ *Email: idamustikawati@gmail.com
}

\begin{abstract}
ABSTRAK
Karena kelangkaan masker bedah, masker respirator N95 maupun masker non medik yang ideal untuk mencegah infeksi virus Corona, maka kini banyak yang menggunakan masker kain sebagai upaya untuk melindungi diri dari virus Corona. Namun, ternyata yang terjadi di luar masker kainpun diperdagangkan dengan harga yang tidak murah. Masker adalah perangkat yang dirancang untuk melindungi pengguna dari menghirup partikel udara dan melindungi kesehatan saluran pernafasan.

Masker jugabiasanya secara rutin digunakan oleh kelompok kerja, ketika teknik dan alat keamanan tidak layak atau tidak efektif untuk mengurangi tingkat debu, maskermenjadi solusi pertahanan terakhir dan sangat sederhana untuk digunakan, masker sendiri menjadi metode yang

efisien untuk melindungi pekerja, dimana lebih dari tiga juta pekerja diwajibkan untuk memakai masker untuk melindungi diri dari bahaya pada pekerjaan. Masker juga dalam masyarakat telah jelas terbukti mengurangi infeksi influenza dibandingkan dengan tidak memakai masker . Banyak berbagai jenis masker, salah satunya adalah masker P100. Masker P100 secara signifikan lebih protektif dibandingkan dari masker N95, dimana masker filter P100 menghasilkan kinerja lebih baik terhadap partikel yang berukuran 10 - $400 \mathrm{~nm}$ dibandingkan dengan masker filter N95 (He et al, 2011). Kata kunci : Makser, bahan, virus
\end{abstract}




\section{Analisis Situasi}

Dari hasil riset terbaru, WHO menganjurkan orang menggunakan masker berbahan kain untuk menutupi bagian hidung hingga dagu. Masker kain dinilai mampu menjadi APD bagi masyarakat sehat ataupun yang merasa sedang tidak enak badan. Jenis masker ini dinilai bisa menghalau penyebaran virus lewat droplet sampai sekitar 70\%. Ada beberapa contoh masker kain yang banyak digunakan oleh masyarakat.

Mengenal jenis-jenis APD dan penggunaannya dalam situasi saat ini menjadi sangat penting. Agar masyarakat tidak harus membeli alat kesehatan yang seharusnya menjadi jatah para tim medis. Contohnya seperti masker bedah dan masker N95. Untuk mengurangi resiko penularan dan mencegah penularan kepada orang lain, pemerintah menyarankan masyarakat yang bukan tenaga medis untuk menggunakan masker kain.

Apalagi ketersediaan masker bedah semakin minim sehingga sulit dicari, belum lagi ada oknum-oknum yang menjual marker dengan harga yang tidak masuk akal, dengan munculnya phenomena semacam ini, banyak orang mulai memikirkan untuk mencari solusi alternative dalam menyiasati kelangkaan masker di tengah pandemi, salah satunya dengan beralih ke masker kain yang lebih hemat.

Adapun kelebihan masker kain antara lain : masker kain dapat dibuat sendiri dengan mudah, penggunaan masker kain dapat di cuci, dapat dipakai berulang-ulang sehingga lebih hemat, tentunya masker kain juga ada kekurangannya.

COVID-19 adalah penyakit yang diakibatkan oleh virus yang pertama kali diidentifikasi di Wuhan, Cina dan dilaporkan ke WHO pada Desember 2019. Pada Januari 2020, WHO menyatakan COVID-19 sebagai pandemik. Kebanyakan orang hanya mengalami gejala penyakit pernapasan ringan. Namun beberapa orang dapat mengalami gejala parah, termasuk pneumonia, yang mengakibatkan kerusakan paruparu dan kematian (Sani, Mariska, Prasetya, 2020). COVID-19 lebih berbahaya untuk mereka yang lanjut 
usia dan memiliki riwayat penyakit kronis seperti diabetes, tekanan darah tinggi dan penyakit jantung (Liu et al, 2020). Kasus pertama dilaporkan di Indonesia pada 2 Maret 2020 dan pada 13 April 2020 pemerintah menyatakan sebagai bencana nasional. Pada 10 April, pemerintah mengeluarkan kebijakan Pembatasan Sosial Skala Besar (PSBB) dimulai di DKI Jakarta, dengan menutup sekolah, tempat kerja, membatasi pergerakan dan menutup tempattempat umum. COVID-19 berdampak pada kehidupan masyarakat dan keadaan ekonomi di Indonesia maupun di dunia.

Adanya wabah Covid-19 ini, hampir seluruh sector terdampak, tak hanya kesehatan. Sector ekonomi juga mengalami dampak serius akibat pandemic virus corona. Tidak dapat dipungkiri, wabah Covid 19 membuat semua sektor ekonomi menjadi lesu dan tidak bisa bertahan. Terutama sangat dirasakan sekali disektor konsumsi Rumah Tangga. Rumah Tangga yang terdampak dari pandemic Covid - 19 adalah dari Pendapatan dan keterbatasan ruang konsumsi Rumah Tangga. Seperti apa dialami ibu-ibu Rumah Tangga di dusun Leces desa Sruni kecamatan Jenggawah kabupaten Jember sebagai pelaku usaha mikro kecil menengah (UMKM).

Salah satu misi pembangunan kesehatan di Indonesia adalah menggerakkan dan memberdayakan masyarakat untuk berPerilaku Hidup Bersih dan Sehat (PHBS). Perilaku Hidup Bersih Dan Sehat (PHBS) merupakan langkah yang harus dilakukan untuk mencapai derajat kesehatan yang optimal bagi setiap orang. Kondisi sehat tidak serta merta terjadi, tetapi harus senantiasa kita upayakan dari tidak sehat menjadi hidup yang sehat serta menciptakan lingkungan yang sehat (MDGs,2015).Upaya peningkatan derajat kesehatan masyarakat yaitu upaya pemerintah mengeluarkan keputusan Menteri Kesehatan, Nomor 1199/Menkes/SK/X/2004 tentang visi promosi kesehatan RI adalah perilaku hidupbersih sehat 2010 atau PHBS 2010. PHBS terdiri dari beberapa indikator khususnya PHBS tatanan institusi pendidikan (pondok pesantren, sekolahan) yaitu mencuci tangan dengan air yang 
mengalir dan memakai sabun, mengkonsumsi jajanan warung/kantin sekolah, menggunakan jamban bersih dan sehat olahraga teratur dan terukur, memberantas jentik nyamuk, tidak merokok, menimbang berat badan dan mengukur tinggi badan setiap bulan dan membuang sampah pada tempatnya (Sari, 2014)

Memakai Masker dapat mencegah berbagai macam penyakit menular, ya itu mencegah terjadinya efek yang disebabkan oleh debu dan bercampur dengan kuman-kuman bertebaran disekitar kita yang terhirup oleh hidung ataupun mulut.

Memakai Masker kadang sangat tidak di perhatikan oleh beberapa orang pada saat mengendarai kendaraan ataupun para Petugas Kesehatan terutama Perawat bersentuhan langsung dengan Pasien pada waktu di RS padahal hampir 50 $\%$ penyakit dapat tertular melalui udara. Kasus-kasus penyakit Dalam dapat menyerang siapa saja baik Anak- anak maupun Orang dewasa yang penularanya melalui hidung ataupun mulut yaitu udara yang tercampur penyakit/kuman
Ada berbagai alasan Orang tidak suka memakai Masker diantaranya belum tahu fungsi dan manfaat Memakai Masker, tidak bisa dalam memakai, tidak tidak terbiasa, tidak tahu perawatanya.

Untuk mempermudah setiap Orang tahu, Fungsi dan Manfaat Memakai Masker, Setiap Tindakan Harus memakai Masker Waktu, Ditempat, Saat yang tepat, Sehinga menjadi Contoh bagi Masyarakat apalagi bagi keluarga pembesuk disarankan memakai masker pada saat membesuk saudaranya yang sedang dirawat di Rumah Sakit supaya hidung ataupun mulut bisa tertutup rapat sehingga secara otomatis tidak menghirup udara yang terkontaminasi dengan kumankuman. Terutama penyakit menular seperti TB Paru (TBC).

Alasan banyak Orang tidak suka Memakai Masker, alasan tidak nyaman disebabkan oleh belum terbiasa perlunya Sosialisasi dalam pemakaian Masker, Alasan yang terakhir tidak bisa/ tahu perawatan Masker, Kita dapat memilih Masker yang bahan dasarnya dari kain yang 
mudah dicuci dengan diterjen Supaya efisien Masker dapat dipakai dikemudian hari sudah terbebas dari kuman.

Banyak ilmuwan dan tenaga medis di seluruh dunia mengadakan riset dalam rangka mengatasi pandemi penyakit virus corona atau Coronavirus Disease 2019 (Covid19) yang masih meluas. Salah satunya mengenai penggunaan masker kain corona untuk mencegah Covid-19. Hal ini dilatarbelakangi ketersediaan masker medis yang terbatas di berbagai negara. Jikapun ada, harganya lebih mahal hingga tiga kali lipat.

Masker adalah perangkat yang dirancang untuk melindungi pengguna dari menghirup partikel udara dan melindungi kesehatan saluran pernafasan. Masker juga biasanya secara rutin digunakan oleh kelompok kerja, ketika teknik dan alat keamanan tidak layak atau tidak efektif untuk mengurangi tingkat debu, masker menjadi solusi pertahanan terakhir dan sangat sederhana untuk digunakan, masker sendiri menjadi metode yang efisien untuk melindungi pekerja, dimana lebih dari tiga juta pekerja diwajibkan untuk memakai masker untuk melindungi diri dari bahaya pada pekerjaan ( $\mathrm{Yu}$ et al, 2014). Masker juga dalam masyarakat telah jelas terbukti mengurangi infeksi influenza dibandingkan dengan tidak memakai masker (Macintyre et al, 2013). Banyak berbagai jenis masker, salah satunya adalah masker P100. Masker P100 secara signifikan lebih protektif dibandingkan dari masker N95, dimana masker filter P100 menghasilkan kinerja lebih baik terhadap partikel yang berukuran 10 - $400 \mathrm{~nm}$ dibandingkan dengan masker filter N95 (He et al, 2011).

Efektivitas penggunaan masker kain corona masih menjadi pembahasan hingga saat ini. Di Indonesia, masyarakat umum diimbau mengenakan masker kain ketika beraktivitas di luar ruangan. Sedangkan masker medis diprioritaskan hanya bagi pasien corona dan petugas kesehatan, terutama yang merawat pasien corona.

\begin{aligned} Pusat & \multicolumn{2}{c}{ Pencegahan dan } \\ Pengendalian & Penyakit Amerika \end{aligned}


Serikat (CDC) lebih dulu mengeluarkan panduan penggunaan masker kain corona bagi warga setempat. Tapi, di sisi lain, WHO menyatakan penggunaan masker kain corona oleh orang sehat belum punya pijakan bukti yang memadai dalam kaitannya dengan pencegahan penyakit Covid-19.

Virus corona merupakan suatu kelompok virus yang dapat menyebabkan penyakit pernafasan pada hewan atau manusia. Virus corona diketahui menyebabkan infeksi saluran nafas pada manusia mulai dari batuk pilek, hingga yang lebih serius seperti Middle East Respiratory Syndrome (MERS) dan Severe Acute Respiratory Syndrome (SARS) (Guan, dkk 2020). Virus corona jenis baru yang ditemukan menyebabkan penyakit COVID19 (WHO, 2020). Sampai saat ini laju persebaran Corona virus Disease-2019 (COVID-19) meningkat semakin cepat melalui tetesan air liur atau keluar dari hidung ketika orang yang terinfeksi batuk ataubersin secara langsung. Upaya pemerintah dalam menanggulangi penyebaran COVID-19 yang sangat cepat ini sudah mencakup banyak aspek kehidupan. Di bidang pendidikan, pemerintah menerapkan pelaksanaan program belajar dari rumah (Kemendikbud, 2020). Hal ini bisa melalui berbagai media berbasis internet maupun melalui media yang tidak berbasis internet (Darmalaksana, dkk 2020). Di bidang sosial masyarakat, pemerintah dengan gencar mencanangkan konsep mitigasi komunitas, berupa pengurangan frekuensi pertemuan besar, pembatasan jarak antar orang di fasilitas umum, hingga penerapan konsep aktivitas yang lebih baik dilaksanakan di rumah (Yunus, dkk 2020). Di bidang kesehatan, pemerintah telah dengan gencarnya mengedukasi masyarakat terkait pentingnya hidup bersih dan sehat, perlunya mengenakan masker saat di luar rumah, pelaksanaan karantina mandiri untuk orang-orang yang memiliki risiko tinggi, serta berbagai pedoman yang bertujuan untuk mencegah penularan COVID-19 
(Telaumbanua, 2020). Di bidang agama pun, pemerintah melalui Majelis Ulama Indonesia (MUI) telah memberikan fatwa terkait dengan pelaksanaan ibadah di masa wabah pandemi COVID-19 (MUI, 2020). Hingga pada tingkat desa, pemerintah telah mengeluarkan protokol terkait Relawan Desa Lawan COVID-19 (Kemendesa, 2020 .

Covid 19 merupakan masalah serius yang harus segera ditangani. Bencana pandemi Corona Virus Disease 2019 (Covid-19) yang menimbulkan dampak pada semua lini kehidupan masyarakat di hampir 270 negara di seluruh dunia, dampak tersebut juga dirasakan di Indonesia. Sejak ditemukannya kasus pertama Covid-19 di Indonesia pada awal bulan Maret 2020, dalam kurun waktu 6 bulan hingga akhir Agustus 2020 telah tercatat 174.796 kasus terkonfirmasi Covid-19 dengan jumlah kematian 7.417 jiwa, meskipun terdapat 125.959 orang penderita yang sembuh dari total 167.379 orang penderita yang masih dirawat (Gugus Tugas Covid-19, per 31 Agustus 2020). Angka resmi yang diterbitkan secara harian oleh Gugus Tugas Covid-19 sejak dibentuknya sampai akhir Agustus 2020 menunjukkan adanya kenaikan kasus yang terinfeksi Covid-19 cukup signifikan, terutama sepanjang MeiJuli 2020. Pada bulan Mei bertambah sebesar 16.355 orang. Pada bulan Juni, kasus positif Covid-19 bertambah sebanyak 29.912 orang. Sementara pada Juli, kasus positif meningkat tajam menjadi 51.991 orang. Memasuki bulan Agustus, tambahan kasus melebihi angka 2.000 per harinya.

Upaya pemerintah dalam menanggulangi penyebaran Covid19 ini sudah mencakup beberapa aspek kehidupan. Di bidang pendidikan, pemerintah menerapkan pelaksanaan program belajar di rumah (Kemendikbud, 2020). Hal ini bisa melalui berbagai media berbasis internet maupun tidak. Di bidang sosial masyarakat, pemerintah dengan gencar mencanangkan konsep mitigasi komunitas, berupa pengurangan frekuensi pertemuan besar, pembatasan jarak antar orang di fasilitas umum, hingga penerapan aktivitas yang dilaksanakan di rumah 
(Yunus, dkk. 2020). Di bidang kesehatan, pemerintah dengan gencarnya mengedukasi masyarakat terkait pentingnya menerakan pola hidup bersih dan sehat, perlunya mengenakan masker saat di luar rumah, pelaksanaan karantina mandiri untuk orang-orang yang memiliki risiko tinggi, serta berbagai pedoman yang bertujuan untuk mencegah penularan Covid-19 (Telaumbanua, 2020). Hingga pada tingkat desa, pemerintah telah mengeluarkan protokol terkait Relawan Desa Lawan Covid-19 (Kemendesa, 2020). Penggunaan masker merupakan salah satu upaya meminimalisir penularan virus antar manusia. Masker adalah perangkat yang dirancang untuk melindungi pengguna dari menghirup partikel udara dan melindungi kesehatan saluran pernafasan. Masker juga biasanya secara rutin digunakan ketika melakukan aktivitas di luar rumah untuk menghindari partikelpartikel berbahaya masuk ke tubuh melalui mulut dan hidung. Sebuah penelitian membuktikan, memakai masker adalah cara paling efektif untuk mencegah penularan virus corona. Agar lebih efektif, peneliti menyebut penggunaan masker di ruang publik perlu ditunjang praktik jaga jarak aman, disiplin karantina, dan pelacakan kontak dari pasien positif Covid-19.

Menggunakan masker saat beraktivitas di luar rumah menjadi hal penting di tengah situasi pandemi saat ini. Pemakaian masker sangat diperlukan untuk meminimalisir penyebaran virus corona jenis baru, masker non medis yang biasanya terbuat dari kain tidak benar-benar efektif untuk melindungi kita dari risiko infeksi virus. Namun, memakai masker non medis tetap bisa melindungi pemakainya dari kemungkinan menyebarkan virus ke orang lain. Itu sebabnya, pemakaian masker bisa memblokir hembusan partikel udara dari individu yang kemungkinan terinfeksi Covid-19 namun tidak memiliki gejala. Dengan memblokir hembusan partikel virus ke udara di sekitar, masker menjaga agar virus tidak menyebar. Selain itu, masker berfungsi sebagai penghalang fisik yang sangat membantu ketika kita 
batuk atau bersin. Tindakan itu dapat menghalangi droplet atau tetesan air liur yang keluar sehingga tidak menyebarkan virus. Udara yang kita hembuskan saat bernafas mengandung tetesan air dari lapisan paru-paru yang membawa bakteri, virus, protein, metabolit, dan senyawa lain yang terlarut.

Gugus Tugas Percepatan Penanganan Covid-19 maupun CDC merekomendasikan penggunaan masker kain bagi masyarakat umum ketika berada di luar ruangan. Terutama saat di tengah situasi yang menyulitkan untuk penerapan aturan jaga jarak fisik (physical distancing), seperti di pasar, supermarket, dan angkutan umum. WHO mendorong negara-negara yang terkena dampak pandemi Covid-19 untuk merekomendasikan masker nonmedis bagi warga masing-masing, termasuk masker kain corona, lantaran masker medis lebih dibutuhkan oleh tenaga kesehatan. CDC juga menyarankan agar tidak memakai masker bedah atau masker N95 karena masker tersebut lebih baik digunakan oleh petugas medis. Namun, tidak semua orang diperbolehkan memakai masker. Kategori orang yang tidak disarankan memakai masker menurut CDC yakni anak-anak di bawah usia dua tahun, siapapun yang kesulitan bernapas, dan orang yang dalam keadaan tidak sadar dan memiliki gangguan fungsi tubuh sehingga tidak bisa melepas masker tanpa bantuan.

Meskipun pemerintah telah melakukan berbagai upaya dalam menanggulangi penyberan Covid-19, penambahan kasus positif Covid-19 di Indonesia terus bertambah. Hal ini disebabkan karena kurangnya pengetahuan terhadap Covid-19 yang berimplikasi terhadap minimnya kesadaran masyarakat sehingga penanganan (pencegahan bagi yang tidak terinfeksi dan atau pengobatan terhadap yang terkena wabah) kurang terintegrasi-interkoneksi dalam sistem pemerintahan di negara kita. Dari pusat (atas) sampai bagian paling bawah (top up-bottom down), yaitu desa/kampung. Desa Tubanan, Kecamatan Kembang, Kabupaten Jepara merupakan tempat tinggal padat penduduk. Lokasi tersebut sering dilalui orang yang berasal dari 
luar daerah karena berada pada kawasan PLTU Tanjung Jati B Jepara. Hal ini menjadi rawan akan terjadinya penyebaran Covid-19 apabila tidak adanya pemahaman dan himbauan untuk mematuhi protokol kesehatan.

Sebagai salah satu civitas akademika yang memiliki tugas Tri Dharma Perguruan Tinggi yang salah satunya adalah pengabdian untuk turut berkontribusi bersama dalam menghadapi Covid-19 (Syahrina, 2020). Melihat situasi dan kondisi di Desa Tubanan Kecamatan Kembang Kabupaten Jepara kami melakukan kegiatan pengabdian kepada masayarakat dalam bentuk kegiatan Kuliah Kerja Nyata (KKN) Unnes dengan tema besar Bersama Melawan Covid (BMC). Kegiatan KKN dengan melakukan edukasi pemahaman dalam penanggulangan Covid-19 melalui protokol kesehatan yang ada. Berdasarkan latar belakang masalah di atas, maka pengabdi tertarik melakukan KKN dengan edukasi di masyarakat Desa Tubanan Kecamatan Kembang Kabupaten Jepara dalam melakukan penanggulangan Covid-19 melalui program edukasi, yakni mengedukasi masyarakat melalui pemberian pemahaman tentang Covid-19 dan pentingnya penggunaan masker, terutama ketika beraktivitas di luar rumah. Selain itu juga diadakan pembagian masker gratis kepada masyarakat dengan tujuan memberikan stimulus kepada masyarakat supaya tertib memakai masker ketika di luar rumah.

\section{Landasan Teori}

a. Definisi Limbah kain

Menurut Paresti, dkk (2016 : 184) limbah adalah sisa proses produksi; bahan yang tidak mempunyai nilai atau tidak berharga lagi sebagai bahan utama dalam pembuatan atau pemakaian suatu produk. Sedangkan menurut Purwanti (2007 : 1) limbah adalah suatu bahan yang terbuang dari sumber hasil aktivitas manusia maupun alam yang belum memiliki nilai ekonomis. Berdasarkan sumbernya limbah dapat berasal dari rumah tangga, pertanian, perkantoran, perusahaan, rumah sakit dan pasar. 
Limbah Kain merupakan salah satu jenis limbah yang sulit diolah, karena merupakan limbah anorganik yang tidak mudah terurai sehingga tidak dapat dikompos. Limbah kain menurut pendapat Paresti dkk (2016 : 40) produksi pakaian yang dilakukan oleh oleh para penjahit atau konveksi sebagai perusahaan pakaian jadi, menghasilkan banyak limbah kain yang biasa disebut kain perca. Kain perca adalah sisa proses penggunaan kain.

Kain perca merupakan gabungan kain kecil-kecil dan motifnya yang berbeda-beda, dapat membentuk suatu kerajinan yang sangat menarik, pemanfaatan kain perca ini dapat mengurangi limbah pabrik kain, karena pada dasarnya untuk mendapatkan potongan yang tepat akan membuang beberapa bagian kain.

Kain perca adalah jenis kain yang merupakan sisa atau limbah pembuatan pakaian atau barang tektil dalam bentuk potongan-potongan kain kecil. Bagi sebagian orang, sisa kain dianggap sebagai sampah sisa produksi. Namun bagi sebagian lain, sisa kain dipandang sebagai limbah bernilai ekonomis. sisa kain juga tidak harus menjadi sampah, sesungguhnya banyak kreasi yang dapat dikembangkan dari potongpotongan sisa kain (Wardana, 2001 : 63) seperti menjadi keset, sarung kotak tisu dan lain-lain termasuk bisa dibuat masker yang lebih ekonomis dan mempunyai nilai estetika.

b. Masker

Masker adalah perlindunan pernafasan yang digunakan sebagai metode untuk melindungi individu dari menghirup zat-zat bahaya atau kontaminan yang berada di udara, perlindungan pernafasan atau masker tidak dimaksudkan untuk menggantikan metode pilihan yang dapat menghilangkan penyakit, tetapi digunakan untuk melindungi secara memadai pemakainya (Cohen \& Birdner, 2012). Masker secara luas daigunakan untuk memberikan perlindungan terhadap parteikel dan aerosol yang dapat menyebabkan bahaya bagi system pernafasan yang dihadapi oleh orang yang tidak memakai alat pelindung diri, bahaya partikel dan aerosol dan berbagai ukuran dan sifat kimia yang berbeda 
dapat membahayakan manusia, maka NIOSH merekomendasikan masker yang menggunakan filter (Eshbaugh et al, 2009).

Mengenal jenis-jenis APD dan penggunaannya dalam situasi saat ini menjadi sangat penting. Ini agar masyarakat tidak mudah membeli alat kesehatan yang seharusnya menjadi jatah para tim medis. Terdapat 3 jenis masker yang disarankan kepada masyarakat agar dapat memutus penyebaran virus corona, antara lain :

- Masker Kain

Dari hasil riset terbaru, WHO akhirnya menganjurkan orang menggunakan masker berbahan kain untuk menutupi bagian hidung hingga dagu. Masker kain dinilai mampu menjadi APD bagi masyarakat sehat ataupun yang merasa sedang tidak enak badan. Jenis masker ini dinilai bisa menghalau penyebaran virus lewat droplet sampai sekitar 70\%.

- Masker Bedah

Masker bedah atau surgical mask lebih disarankan untuk penggunaan oleh tenaga medis. Namun, jenis masker yang biasanya terdiri atas tiga lapisan ini juga diperkenankan bagi masyarakat yang sedang sakit. Tujuannya adalah mencegah penyebaran virus. Masker bedah bersifat anti-air dan memiliki filter antikuman yang dapat menghalau percikan air liur, yang menjadi sumber penyebaran virus serta bakteri. Masker ini juga memiliki lapisan dalam yang bisa menyerap cairan dari mulut Anda sehingga air liur pun tidak akan terpercik ke luar.

- Masker N95

Inilah jenis masker medis yang paling disarankan untuk menghalau penularan virus corona. Masker N95 memiliki kemampuan menghalau percikan air liur serta partikel virus di udara. Kemampuan ini sangat dibutuhkan tim medis yang kerap berhadapan dengan virus yang mampu bertahan di udara secara singkat akibat cipratan dari pasien atau aerosol, seperti corona virus. Masker N95 sangat ketat ketika dikenakan guna memastikan tidak ada celah yang bisa disisipi virus atau bakteri. Masker yang lebih efektif untuk mencegah virus Corona adalah masker N95. Masker ini terbuat dari bahan polyurethane dan 
polypropylene yang mampu menyaring hampir 95\% partikel berukuran kecil. Masker N95 memiliki bentuk yang dapat menutup area mulut dan hidung dengan lebih rapat, bila ukurannya sesuai.

Masker dikenal dengan alat pelindung diri. Sebagai alat pelindung diri, masker dirancang untuk memberikan perlindungan kepada pemakainya dan bukan sebaliknya menjadi sarana trasmisi atau penularan karena penggunaan yang salah. Menggunakan masker sangat efektif dalam pencegahan virus corona. Untuk saat ini pemerintah sangat gencar untuk mengkampanyekan pemakaian masker, mulai dari sanksi social hingga denda.

c. Nilai Estetika

Nilai estetika sebuah karya secara umum terkandung dalam bentuk dan isinya. Bentuk terkait dengan elemen dan struktur, sedangkan isi lebih kepada kandungan nilai yang disampaikan oleh karya dengan rangkaian elemen dan struktur rupa. Dalam sebuah produk, untuk menambah nilai keindahan sebuah karya kerajinan agar lebih menarik adalah kreteria estetika.

Nilai estetika memiliki sifat obyektif maksudnya adalah bahwa nilai keindahan suatu obyek seni terletak pada wujudnya, sehingga bisa dilihat atau diamati secara kasat mata. Pada sifat obyek ini, nilai estetika (keindahan) suatu karya seni sesungguhnya tersusun dari sejumlah hal seperti komposisi, perpaduan warna, penempatan obyek dan lain sebagainya. Keselarasan dan kesesuaian dalam menata unsur visual tersebutlah yang kemudian mewujudkan nilai keindahan suatu karya seni.

Nilai estetika adalah istilah lain bagi nilai keindahan. Sedangkan contoh factor yang dinilai di masyarakat antara lain :

- Berkaitan dengan kecantikan / ketampanan

- Pemandangan Alam

- Seni rupa

- Seni tari

- Seni music

- Pembuatan suatu produk

- Arsitektur

- Batik di Indonesia. 
Nilai estetis artinya sesuatu yang dinilai indah (penilaian menggunakan panca indra kita). Estetis atau estetika ialah penampilan, penilaian yang biasanya diterapkan pada estetika ialah keindahannya.

\section{d. Ekonomis}

Ekonomis itu adalah suatu tindakan/perilaku dimana kita dapat memperoleh input (barang atau jasa) yang mempunyai kualitas terbaik dengan tingkat harga yang sekecil mungkin . dari pengertian diatas ada 2 unsur yang sangat penting, yaitu sumber daya (biaya) dan input (barang atau jasa). Individu atau korporasi yang ekonomis selalu memilih barang atau jasa dengan harga yang murah dan kualitas yang baik. Dari sekilas pengertian diatas kita dapat melihat bahwa barang yang ekonomis itu bukan merupakan barang murahan atau barang asal jadi.

\section{Identifikasi dan Perumusan} Masalah

Dari uraian tersebut di atas, maka identifikasi dan rumusan masalah adalah sebagai berikut : “ Bagaimanakah cara memberikan pengetahuan baru tentang manfaat limbah kain (Perca) yang tidak berharga dapat menjadi barang (masker) yang mempunyai nilai guna, berkualitas, estetika/keindahan, nilai jual dan menjadi sumber pendapatan baru yang menjanjikan."

\section{Tujuan Kegiatan}

Tujuan yang diperoleh dari kegiatan pelatihan ini, peserta dapat membuat masker dari limbah kain (Perca) sendiri dan juga dapat dikembangkan untuk dijadikan sebagai pengetahuan baru yang dapat dijadikan sebagai produk dengan bahan sangat murah/tidak ada harganya tetapi menjadi barang tetap berkualitas dan mempunyai nilai estetika yang sangat menarik untuk di pasarkan.

\section{Manfaat Kegiatan}

Peserta pelatihan dapat mengembangkan kreativitas dalam 
membuat masker untuk menciptakan sesuatu hal yang baru, berupa model masker yang bersifat inovatif, artinya dapat berupaya menemukan kombinasi baru, konstruksi baru yang memiliki kualitas yang berbeda dengan sebelumnya (Mei Ie : 2020), seperti misalnya membuat masker model baru atau dengan memperindah masker dengan berbagai teknik hiasan sebagai karya seni yang indah (estetika).

\section{Kerangka Pemecahan Masalah}

Berdasarkan kebutuhan

dilapangan diperoleh gambaran bahwa dengan permasalahanpermasalahan ditengah pandemic Covid-19, sector ekonomi yang terpuruk terutama Rumah Tangga usaha yaitu pelaku usaha mikro kecil menengah (UMKM), dan Rumah Tangga pendapatan yang terjadi karena Pemutusan Hubungan kerja (PHK), pemotongan gaji yang menimbulkan menurunnya tingkat konsusmsi Rumah Tangga, maka pembuatan masker dari limbah kain (Perca) menjadi salah satu cara atau strategi untuk melindungi diri dari tertularnya virus Coid - 19 dan dapat menjadi peluang bisnis dengan memanfaatkan bahan yang tidak berharga menjadi produk masker yang mempunyai nilai estetika/ keindahan dan berkualitas yang menguntungkan.

\section{Khalayak Sasaran}

Kegiatan pelatihan ini di ikuti oleh 15 orang yang terdiri dari ibuibu muslimat dan siswa-siswi SMK Salafiyah Miftahul Huda jurusan Tata Busana. Pelatihan ini dilaksanakan di rumah $\mathrm{Ibu}$ Musa'adah dusun Leces desa Sruni kecamatan Jenggawah kabupaten Jember, dengan harapan ibu-ibu muslimat dan siswa-siswi SMK tersebut dapat membuat masker kain dengan memanfaatkan bahan limbah yang sering dianggap sampah yang tidak berharga untuk dapat dijadikan masker kain yang mempunyai nilai guna, hemat, mempunyai nilai keindahan, berkualitas dan dapat digunakan sendiri juga mempunyai peluang untuk dipasarkan.

\section{Metode Kegiatan}

Metode kegiatan pelatihan diawali dengan survey lapangan 
terlebih dahulu, permohonan ijin kepada penanggung jawab wilayah, serta mengumpulkan khalayak sasaran yaitu ibu-ibu muslimat dan siswa-siswa SMK Salafiuah Miftahul Huda jurusan Tata Busana dusun Leces Desa Sruni kecamatan Jenggawah kabupaten Jember untuk melaksanakan kegiatan pelatihan dengan menggunakan pendekatan utama yaitu:

- Sosialisasi program

- pemberian/penyampaian materi.

- pelatihan dan pendampingan.

- dilaksanakan : Sabtu, 28 November 2020 .

- waktu : 10.00 - 12.00 WIB.

Pelatihan pembuatan masker dari limbah kain merupakan kegiatan praktek dari materi yang telah diberikan atau disampaikan. Sedangkan pendampingan merupakan kegiatan dalam menghasilkan produk, dilaksanakan setelah pelatihan diberikan yaitu dari limbah kain untuk dibuat masker sendiri.

Memberikan pelatihan membuat masker dari limbah kain (kain perca) yang semula dianggap tidak berharga bisa menjadi produk (masker) dengan berbagai macam model dengan kreasi yang dapat menghasilkan produk masker yang menarik, indah dan fashenable yang bisa dipakai oleh berbagai kalangan tua muda, jenis pekerjaan dan status social, dan yang terpenting dapat menjadi sumber pendatan baru yang cukup menjanjikan bagi Rumah Tangga.

\section{Evaluasi Kegiatan}

Respon ibu-ibu muslimat dan siswa-siswa SMK Salafiyah Miftahul Huda jurusan Tata Busana dalam mengikuti pelatihan membuat masker kain dari limbah kain (perca) sangat baik. Hal ini dilihat dari peserta sangat antusias mengikuti pelatihan dari awal sampai akhir dan ingin mencoba lagi membuat masker dengan kreasinya masing-masing. Pada akhir kegiatan pelatihan, ibuibu muslimat dan siswa-siswa SMK Salafiyah Miftahul Huda sruni di beri sumbangan bahan-bahan untuk dapat digunakan oleh siswa setelah memperoleh pelatihan untuk membuat masker sendiri di rumah sebagai PR (pekerjaan rumah). Kegiatan pelatihan mendapat 
sambutan yang sangat baik dari ibuibu muslimat dusun Leces maupun siswa-siswa SMK Salafiyah Miftahul Huda jurusan Tata Busana dan berjanji untuk melanjutkan latihan di rumah untuk membuat masker.

Kemampuan peserta dalam mengikuti latihan membuat masker dari limbah kain cukup baik, hal ini dapat dilihat dari hasil masker yang dibuat sudah bagus dan rapi, walaupun masih ada beberapa peserta hasil kerjanya kurang rapi bentuknya kurang bagus. Artinya secara keseluruhan dapat dikatakan berhasil.

\section{DAFTAR PUSTAKA}

Ie, Mei. 2020, Kreativitas dan Inovasi Bidang Kerajinan untuk Meningkatkan Jiwa Wirausaha Siswa.

Purwanti, Endang, 2007, Sampah Jadi Uang, Klaten; Saka Mitra Kompetensi.

Wardana, Enen, 2001, Membuat Aneka Kerajinan Dari Kain Perca, Jakarta : Puspa Swara. 